International Journal of Civil Engineering and Technology (IJCIET)

Volume 9, Issue 12, December 2018, pp. 1006-1015, Article ID: IJCIET_09_12_103

Available online at http://www.iaeme.com/ijciet/issues.asp?JType=IJCIET\&VType=9\&IType=12

ISSN Print: 0976-6308 and ISSN Online: 0976-6316

(C) IAEME Publication

Scopus Indexed

\title{
MULTIFACTOR APT APPROACH TOWARDS PREDICTED PATTERNS OF LONG-TERM ASEAN FINANCIAL MARKET INTEGRATION
}

\author{
Rahmat Hidayat, Efrizal Adil Lubis, Rusiadi, Ade Novalina, Anwar Sanusi, A. P. U. \\ Siahaan, Dewi Maharani Rangkuti and Lia Nazliana Nasution \\ Universitas Pembangunan Panca Budi, Medan, Indonesia
}

\begin{abstract}
The purpose of this study is to obtain a predictive pattern of the integration of ASEAN financial markets with the Multifactor Arbitrage Pricing Theory (APT) approach. The specific target in this study is Analyzing the effectiveness of the Multifactor APT Model in forming a predictive pattern of financial market integration in Southeast Asian countries, both in the short, medium and long-term. Establish the fastest and most appropriate ASEAN country in predicting financial market integration in Southeast Asian countries, both in the short, medium and long-term. The hypothesis in this study is that the Multifactor APT model is useful in forming a predictive pattern of financial market integration in Southeast Asian countries. Indonesia is the fastest and appropriate ASEAN country to use in predicting the occurrence of financial market integration in Southeast Asian countries. The data analysis model used is Vector Autoregression (VAR), Impulse Response Function (IRF), Forecast Error Variance Decomposition (FEVD). The assumption test used is Stationarity Test, Cointegration Test, Lag Stability Test, VAR Structure and Determination of Optimal Lag Levels. The results of data analysis with VAR are expected to be able to form a pattern of predictions of effective financial market integration in ASEAN countries. Varian Decomposition results can determine which ASEAN countries are the fastest and most appropriate in predicting the occurrence of financial market integration in Southeast Asian countries, both in the short, medium and long-term.
\end{abstract}

Keywords: Financial Market Integration, Multifactor Arbitrage Pricing (APT), Vector Autoregression

Cite this Article: Rahmat Hidayat, Efrizal Adil Lubis, Rusiadi, Ade Novalina, Anwar Sanusi, A. P. U. Siahaan, Dewi Maharani Rangkuti and Lia Nazliana Nasution, Multifactor Apt Approach towards Predicted Patterns of Long-Term Asean Financial Market Integration, International Journal of Civil Engineering and Technology, 9(12), 2018, pp. 1006-1015

http://www.iaeme.com/IJCIET/issues.asp?JType=IJCIET\&VType=9\&IType $=12$ 


\section{INTRODUCTION}

Based on the global financial factors that need to be studied in this study is the existence of global financial market integration, both in the European region, America, Asia, and ASEAN. Integration of regional capital markets or the so-called Association of Southeast Asian Nations (ASEAN) began in 1967. Initially, ASEAN was more of a collaboration in politics, then expanded more broadly, including the economic sector. At the October 2003 ASEAN Summit in Bali in the declaration of the ASEAN Concord II (Bali Concord II) agreed on the establishment of the ASEAN Economic Community (AEC) which will commence 31 December 2015[1]. AEC is the realization of the aspirations of ASEAN as an open, inclusive, dynamic and resilient region in 2020 [2]. The programs aimed at AEC not only include freedom of goods flow, labor, capital flows but also reduce poverty and social inequality [3].

The Indonesian capital market through the Indonesia Stock Exchange (IDX) has one of the standard index indicators, such as the Jakarta Composite Index (JKSE). JKSE is an index used in measuring the performance of all shares listed on the Indonesia Stock Exchange (IDX). JKSE on the IDX includes price movements for ordinary shares and preferred shares [4]. Market developments and movements have caused JKSE to experience periods of up and down. On March 6, 2015, JKSE reached the highest level in history, which closed up 1.17 percent to the highest level of 5,514.78 [5]. The following is the development of the market.

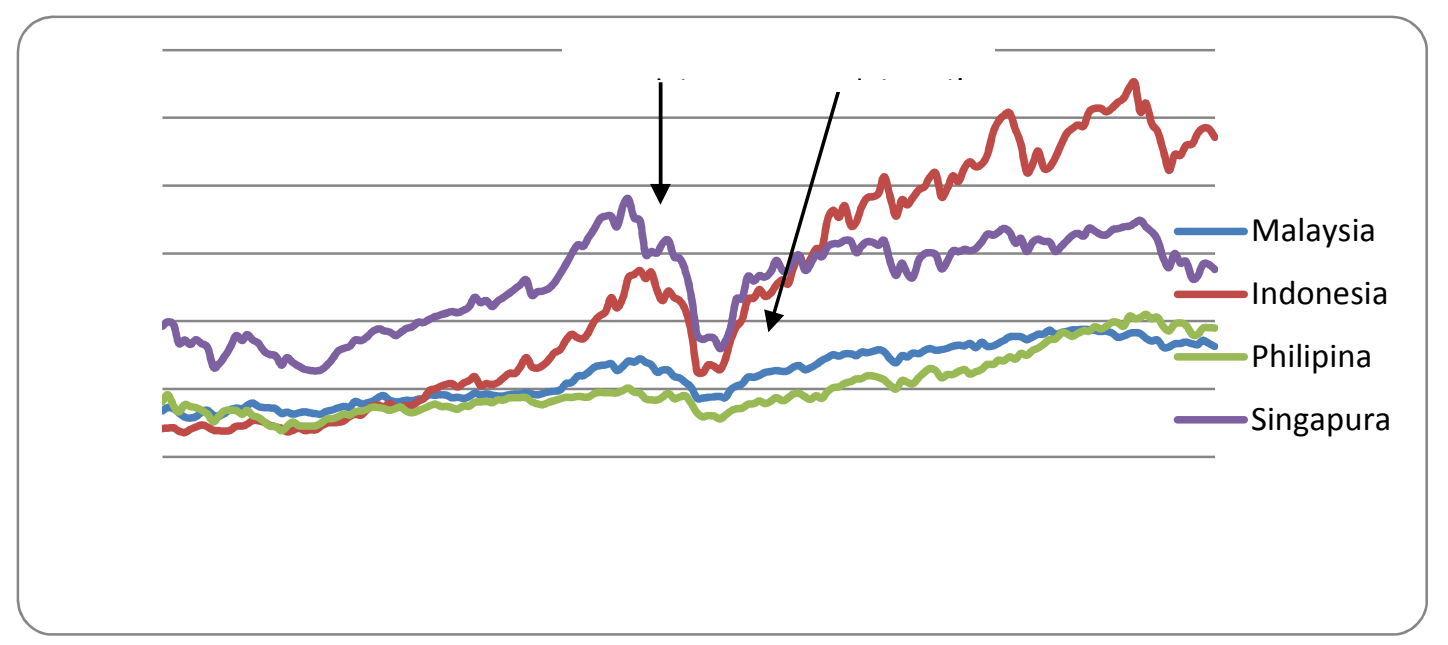

Figure 1. Development of four ASEAN countries stock indices from 2000 to 2015

Figure 1 explains that there are three forms of financial market integration, such as during the booming economy of 2007 and the global financial crisis in 2008, then the third integration was in a booming condition in 2014. During the subprime mortgage crisis in America (2008), not only Indonesia experienced a decline in its stock price index, but ASEAN countries such as the Philippines, Malaysia, Singapore were also affected. Shown in Figure 1.1 When the crisis hit America, the four countries' indexes, PSE, KLCI, and STI, were also driven by falling charts (third integration). ASEAN countries that are still classified as developing countries are still vulnerable to the conditions of the world economy. The subprime mortgage crisis in America had an impact on the decline of stock exchanges in America and was followed by stock exchanges in ASEAN. The subprime mortgage crisis has a negative impact on the capital market, especially developing country capital markets [6]-[8].

The Asian economy, especially the southeast region, are interrelated with each other through trade and investment so that the economic conditions reflected in the index movement 
will affect other countries. This phenomenon is evidenced by empirical studies that ASEAN capital markets are cointegrated [9]-[13]. ASEAN capital markets are an inseparable part of the global capital market [14]-[16]. Empirical research on the effect of global indices on the ASEAN capital market or one of the countries in Asia has been done [17]-[21], but previous studies did not use the multifactor APT approach and long-term analysis.

This research also examines the domino (contagion) effects between ASEAN countries. Contagion as a significant increase in cross-market relations after a shock in a country (or group of countries), as measured by a comparison of asset prices or the joint movement of financial flows in the market against a co-movement in a stable period. Geographical proximity and similarity of characteristics enable countries in the Asian region to have a very high domino effect [22]. Based on several explanations, it is known that the existence of the geographical domino effect can form financial market integration. In this case, when the financial market is formed, a Multifactor APT balance model is needed which can create a balance between the law of one price and the integration of the financial markets of Southeast Asian countries.

\section{THEORIES}

\subsection{Multifactor Arbitrage Pricing Theory (APT)}

Ross formulated a balanced model called Arbitrage Pricing Theory (APT), which states that two investment opportunities that have identical characteristics cannot be sold at different prices [23]. In this case, the law adopted by APT is the law of one price. An asset that has the same characteristics (identical to the same) if sold at a different price, there will be an opportunity to arbitrage by buying assets of low value and at the same time selling them at a higher price to obtain profit without risk [24]-[27].

In the economy of a country, there are four known markets, such as the capital market, money market, foreign exchange market, and the goods market. Of the four markets that are strictly interrelated and that reflect the law of one price (the law of one price) are generally three markets, such as capital markets, money markets, and the foreign exchange market. All three markets have the same balance and are identical so they cannot be sold at different prices. If there is no balance from these markets, the arbitrage process will occur from one market to another as described above.

Regarding the capital market, the APT model states that the rate of profit from shares traded in the capital market consists of two components, such as the level of ordinary profit or the expected level of profit and the level of uncertain or risky profits. The expected level of profit is part of the level of actual profits expected by investors. Information held by investors strongly influence this level of profit. While the level of profit that is uncertain or part of the level of profit derived from information that is not expected. Investors in carrying out their activities face two types of risks, such as systematic risk and unsystematic risk. Both of these risks affect the level of profit expected by investors. The non-systematic risk from one company does not correlate with other companies.

Conversely, the systematic risk will correlate with each company (stock). It is because the factors that influence systematic risk are the same, for example, inflation rates, exchange rates, interest rates, and other variables or often referred to as macroeconomic variables. Therefore changes in macroeconomic variables will affect all companies (shares). However, there may be differences in the magnitude of changes in macroeconomic variables on stock prices.

The factor model bases itself on the assumption that there is a linear relationship between the price of a stock and the price of all shares on the stock represented by a market index. By that assumption, the profit level of stock will correlate with changes in market prices. As a 
reward-producing process, the factor model seeks to include the main economic forces that systematically move or influence the prices of all stocks Implicitly, in the arrangement of factor models there is an assumption that the rewards between two stocks will be correlated, i.e. moving together - only through the same reaction to one or more factors determined by the model. The factor model can provide the information needed to calculate the expected benefits, variants as well as the covariance of each share, the result is that a factor model is a useful tool for portfolio management [28].

The multi-factor model assumes that the process of determining stock prices involves several factors. It means that several possibilities are more than one factor (pervasive factor) in the economy that affects stock prices. The economic situation affects almost all companies. So changes in the forecast economy have a significant impact on the prices of most shares.

For example, two sources of macroeconomic risk are GDP and interest rates that cannot be ascertained regarding stock prices. In simple terms the multi-factor model of equations can be stated as follows:

$$
\mathbf{R}_{\mathbf{i}}=\mathbf{E}\left(\mathbf{r}_{\mathbf{i}}\right)+\beta_{\mathrm{iGDPGDP}}+\beta_{\mathrm{iIR}} \mathrm{IR}+\mathbf{e}_{\mathbf{i}}
$$

Two factors on the right side are similar to the systematic factor in the economy. As with the single factor model, these two macro factors have zero expectation values: indicating changes in this variable that were previously not anticipated. The coefficient on each factor has the above equation measuring the sensitivity of stock returns on that factor. For this reason, coefficients are often referred to as sensitivity, loading, or beta factors. Moreover, $e_{i}$ reflects the influence of company-specific factors.

\subsection{Financial Market Integration and Contagion Theory (Domino Effects)}

The capital market is defined as a market for various long-term financial (or securities) instruments that can be traded, whether in the form of debt or equity, whether issued by the government or issued by the private sector. In the capital market financial instruments are traded such as stocks, bonds, warrants, rights, convertible bonds, and various derivative products such as options (putt or call).

Appleyard \& Feld say "... much of international trade is taking place in a context where countries accord differential treatment of their trading partners. This treaty occurs by way of economic integration, where countries join together to create larger economic units with special relationships among the members ... " [29]. In the book, it is explained that countries that are engaged in international trade have formed a trade alliance (Economic Integration), which had previously had special inter-state relations.

Economic integration can be divided into four categories, such as Free Trade Area, Customs Union, Common Market, and Economic Union. Each country can enter into one of these categories. Thus, money market integration can be interpreted as a relationship that occurs between money markets in two or more countries where if one market experiences shock in the form of changes in interest rates, increases in inflation or others will have an influence both in the long and short-term integrated state money market.

The effect it causes can be positive or negative. Money market integration that occurs has indicators that can always be used as a reference or proof of money market integration [30][34]. These references include inflation, interest rates, national income, exchange rates, savings, investments and so on. The interest rate itself is divided into long-term interest rates and short-term interest rates. In this study, the indicators taken are short-term interest rates, such as deposit rates (monthly). Deposit rates are considered very sensitive to various economic changes compared to other interest rates. It is the nature of deposit rates included in short-term 
interest rates. It is from this indicator of deposit rates that it can be seen whether there is money market integration or not between countries. If money market integration occurs, the results of the analysis will show the same trend for each country, in other words, the increase or decrease will occur together from the period to the next period or before. This opinion is corroborated by what Laopodis wrote.

Money market integration that occurs has many implications, such as the macro variables, such as exchange rates. Besides the exchange rate of money market integration, it also influences the financial markets of a country. The implications of money market integration on the exchange rate can be divided into two, such as the implications for countries with floating exchange rates and in countries that use fixed exchange rates. The implications for exchange rates are usually associated with emerging real devaluations.

The financial market implications for a country with a floating exchange rate system are when there is a devaluation. Devaluation can increase the foreign debt burden, worsen the price situation and can cause risk premium. Furthermore, this adverse effect will be partially offset with a positive effect on the asset side with rising domestic demand. Like the previous specifications, under a floating exchange rate regime, where the central bank determines domestic output prices, the settlement of a devaluation is done by nominal depreciation separating real product wages, and therefore labor flows do not change, but what will happen is the increase in investment and output in the future front. Whereas a country with a fixed exchange rate system that can be done to complete real devaluation is by deflation will increase real product wages and will cause a decrease in labor flows and output flows. The decrease in output flow will reduce the price level so that it will push risk premium even further and reduce investment and future output even more than if the floating exchange rate is applied (floating exchange rate policy). Among the two models above, it is more promising for prosperity than the fixed exchange rate policy.

Skeptics argue that the contemporary world economy is significantly less open and globalized when compared to economic conditions in the 19th century. It is as happened in the period of the belle époque (the golden age of the world economy) in 1890-1914, the scale and scale of geography and flows trade, capital, and migrants today experience a decline in integration towards the global. If economic globalization is associated with increasing national economic integration, where functional organizations from economic activities have actively participated in influencing national government decisions, then, in theory, it can be said that the global economy has been born. In the global economy, theoretically, the strength of the world market is expected to have more power than the condition of the national economy as the real value of the leading economic variables (production, price, wages, and interest rates) in responding to global competition. If globalization is right, there is a single global market presence.

\subsection{Contagion Effect Theory}

Contagion is defined as a significant increase in cross-market relations after a shock in a country (or group of countries), as measured by a comparison of asset prices or a joint movement of financial flows in the market against a co-movement in a stable period. Geographical proximity and similarity of characteristics enable countries in the Asian region to have a very high domino effect. Dornbusch [35] suggest three definitions of contagion. First, contagion can be interpreted as a crisis in a country, and the crisis in that country has caused speculative attacks on other countries. An example is a massive attack that caused Brazil to suffer in late 1998 after Russia fell. Second, contagion in the restrictive sense is a transmission from a shock to cross national borders, or in general, a significant correlation between countries 
occurs outside the fundamental relationship between the state and outside the standard shocks. Contagion in the restrictive sense is usually referred to as an excess co-movement and is generally explained by herd behavior. Third, contagion is in a very restrictive sense, a phenomenon that occurs when the correlation between countries increases during the crisis period compared to when the economy is average. Four criteria can be used to detect the presence or absence of a contagion effect, such as based on the correlation of asset prices, the conditional probability of a currency crisis, the transmission of changes in volatility and the movement of capital flows [36].

Domino theory is a phenomenon of chain change based on geo-strategic principles. The pattern of change is analogous to that of the Chinese domino (mahjong) that stands upright, if the earliest domino is dropped, it will overwrite the closest domino, and this process will continue to the last domino chip. The domino effect occurs because the existence of strong market theory influences weaker markets [37]. The cause of contagion consists of several causes such as fundamental and behavior of investors.

\section{METHODOLOGY}

The research approach is quantitative with the support of the Vector Autoregression (VAR) model, which is used as a predictive analysis tool. The material to be used in this study is related to Multifactor Arbitrage Pricing Theory (APT). Observation of the data used is time series data in 72 quarters, such as the first quarter of 2000 to the fourth quarter of 2015. This study uses secondary data types with time series in quarterly, such as the first quarter of 2000 to the fourth quarter of 2015 - secondary data derived from primary data that has been processed and presented as further information, both in table form and not. While time series data is a set of data from certain phenomena obtained at particular time intervals such as weeks, months and years. Data sources were obtained from Yahoo Financial Data, Bank Indonesia, the Indonesian Ministry of Finance and the Indonesian Central Bureau of Statistics.

\subsection{Vector Autoregression (VAR)}

This test is carried out to determine whether there is a simultaneous relationship (interrelated) between variables, as exogenous variables and endogenous variables by including time (lag). This model can make predictive patterns of financial market integration in the short, medium and long-term of the effects of simultaneity between variables. VAR testing can be done using the following formula.

$$
\begin{aligned}
& J K S E_{t}=\beta_{10} J K S E_{t-p}+\beta_{11} P S E_{t-p}+\beta_{12} K L C I_{t-p}+\beta_{13} S T I_{t-p}+\beta_{14} G D P_{t-p}+\beta_{15} \text { Bunga }_{t-p}+e_{t 1} \\
& P S E_{t}=\beta_{20} J K S E_{t-p}+\beta_{21} P S E_{t-p}+\beta_{22} K_{C C I_{t-p}}+\beta_{23} S T I_{t-p}+\beta_{24} G D P_{t-p} \beta_{25} \text { Bunga }_{t-p}+e_{t 2} \\
& K L C I_{t}=\beta_{30} J K S E_{t-p}+\beta_{31} P S E_{t-p}+\beta_{32} K_{C C I_{t-p}}+\beta_{33} S T I_{t-p}+\beta_{34} G D P_{t-p} \beta_{35} \text { Bunga }_{t-p}+e_{t 3} \\
& S T I_{t}=\beta_{40} J K S E_{t-p}+\beta_{41} P S E_{t-p}+\beta_{42} K L C I_{t-p}+\beta_{43} S T I_{t-p}+\beta_{44} S E T_{t-p}+\beta_{45} \text { Bunga }_{t-p}+e_{t 4}
\end{aligned}
$$

\begin{tabular}{|c|c|}
\hline JKSE & $=$ Indonesian Stock Financial Value (Point) \\
\hline PSE & $=$ Philippine Stock Financial Value (Point) \\
\hline KLCI & $=$ Malaysian Stock Financial Value (Point) \\
\hline STI & $=$ Singapore Stock Financial Value (Point) \\
\hline Bunga & $=$ SBI Interest Rate $(\%)$ \\
\hline GDP & $=$ Exchange rate of dollars to rupiah (billion) \\
\hline & $=$ Random Disturbance \\
\hline
\end{tabular}

Where: 
$=$ lag length

\section{RESULT AND DISCUSSION}

Based on the results of the research shown in Table 4.44, the results of CD in the short term (period 1) show that the estimated variance error of $12.6 \%$ is explained by CD itself. The other variable that most influences $\mathrm{CD}$ as a policy variable other than CD itself is GDP of 5.55\%, INTEREST of $32.9 \%$, KURS of 1.29 then followed by SHARES of 47.55. In the middle term (period 12) the estimated error variance of $4.19 \%$ is explained by CD itself. The other variable that most influences CD as a policy variable other than CD itself is GDP of 6.64\%, INTEREST is $36.9 \%$, KURS is 9.37 then SHARE is $41.9 \%$. In the long run (period 24) the estimated error variance of $4.35 \%$ is explained by CD itself. The other variable that most influences CD as a policy variable other than CD itself is GDP of $7.32 \%$, INTEREST of $36.5 \%$, KURS of $11.6 \%$, and SHARES of $40.16 \%$.

Table 1. Policy Recommendations for CD

\begin{tabular}{|c|c|c|c|}
\hline Period and Percentage & CD & Max 1 & Max 2 \\
\hline Short-term & & SHARE & INTEREST \\
$\%$ & $12.6 \%$ & $47.55 \%$ & $32.9 \%$ \\
\hline Medium-term & & SHARE & INTEREST \\
$\%$ & $4.19 \%$ & $41.9 \%$ & $36.9 \%$ \\
\hline Long-term & & SHARE & INTEREST \\
$\%$ & $4.35 \%$ & $40.16 \%$ & $36.5 \%$ \\
\hline
\end{tabular}

Based on the previous table, it is known that the policy to control foreign exchange reserves turns out to be from the foreign exchange reserves themselves, both short, medium and longterm. Then the policy recommendation other than investment itself is through interest rates. The SHARE itself explains the result of that SHARES in the short term (period 1), the estimated error variance of $100 \%$. While the KURS, INTEREST, GDP and CD variables do not respond. In the middle term (period 12) the estimated variance error of $47.9 \%$ is explained by the SHARE itself. The other variable that has the greatest influence on SHARES as a policy variable other than SHARE itself is GDP of $2.87 \%$, CD of $9.01 \%$, INTEREST of $17.11 \%$, KURS of $23.03 \%$. In the long run (period 24) the estimated variance error of $28.57 \%$ is explained by the SHARE itself. Other variables that most influence STOCK as a policy variable other than SHARE itself are CDs of $7.61 \%$, GDP of 1.76, INTEREST of $19.72 \%$, then KURS of $42.31 \%$.

Table 2. Policy Recommendations for SHARE

\begin{tabular}{|c|c|c|c|}
\hline Period and Percentage & SHARE & Max 1 & Max 2 \\
\hline Short-term & & SHARE & SHARE \\
$\%$ & $100 \%$ & $100 \%$ & $100 \%$ \\
\hline Medium-term & & SHARE & KURS \\
$\%$ & $47.9 \%$ & $47.9 \%$ & $23.03 \%$ \\
\hline Long-term & & KURS & SHARE \\
$\%$ & $28.57 \%$ & $42.31 \%$ & $28.57 \%$ \\
\hline
\end{tabular}

Based on short-term, mid-term and long-term tables, another variable that can be used as a recommendation for controlling stocks in the short, medium and long-term is KURS. 
Rahmat Hidayat, Efrizal Adil Lubis, Rusiadi, Ade Novalina, Anwar Sanusi, A. P. U. Siahaan, Dewi Maharani Rangkuti and Lia Nazliana Nasution

\section{CONCLUSION}

Based on the results of the analysis and discussion that has been done, several conclusions can be taken. This study has a good model, where the model specifications that are formed have a stable result, which shows that all root units are in a circle of images Inverse Roots of AR Characteristic Polynomial. The result of the Analysis of Vector Autoregression using the basis of lag one shows that there is a contribution from each variable to the variable itself and other variables. The results of the Vector Autoregression analysis also show that the past variable ( $t-$ 1) contributes to the present variable both towards the variable itself and other variables. From the estimation results, it turns out that there is a reciprocal relationship between one variable and another contributing variable. Analysis Results The Impulse Response Function shows the existence of other variable responses to changes in one variable in the short, medium and longterm, and it is known that the stability of the responses of all variables is formed in periods of 20 or medium and long term. The response of other variables to changes in one variable shows different variations both from positive responses to negative or vice versa, and there are variables whose responses remain positive or remain adverse from short to long term. The results of the Variance Decomposition Analysis show that there are variables that have the most significant contribution to the variable itself both in the short, medium and long-term. Moreover, for those who contributed little to the variables themselves in the short, medium and long-term.

\section{REFERENCES}

[1] ASEAN, "ASEAN I ONE VISION ONE IDENTITY ONE COMMUNITY." [Online]. Available: https://asean.org/. [Accessed: 19-Dec-2018].

[2] R. B. Guerrero, Regional Integration: the ASEAN Vision in 2020. IFC Bulletin No. 32., 2010.

[3] H. Soesastro, "Kebijakan Persaingan, Daya Saing, Liberalisasi, Globalisasi,Regionalisasi dan Semua Itu," CSIS Econ. Work. Pap. Ser. WPE08, 2004.

[4] Y. Hartono, Teori Portofolio Dan Analisis Investasi, Cetakan Keenam. Yogyakarta: Universitas Gadjah Mada, 2009.

[5] IDX, "PT. Bursa Efek Indonesia." [Online]. Available: https://www.idx.co.id/. [Accessed: 19-Dec-2018].

[6] K. Heilmann, Stock Market Linkages - A Cointegration Approach. University of Nottingham, 2010.

[7] J. Aswani, Analyzing the Impact of Global Financial Crisis on the Interconnectedness of Asian Stock Markets using Network Science. Mumbai: Indira Gandhi Institute of Development Reseach, 2015.

[8] T. P. Thao and K. Daly, "The Impacts of the Global Financial Crisis on SoutheastAsian Equity Markets Integration,” Int. J. Trade, Econ. Financ., pp. 299-304, 2012.

[9] M. Shabri Abd. Majid, A. Kameel Mydin Meera, M. Azmi Omar, and H. Abdul Aziz, "Dynamic linkages among ASEAN-5 emerging stock markets," Int. J. Emerg. Mark., vol. 4, no. 2, pp. 160-184, Apr. 2009.

[10] F. Carrieri, V. R. Errunza, and K. Hogan, "Characterizing World Market Integration Through Time," SSRN Electron. J., 2001.

[11] K. Guesmi, "Characterizing South-East Asian Stock Market Integration through Time," Int. J. Bus., vol. 17, no. 1, 2012.

[12] R. J. Patel, "Co-Movement and Integration Among Stock Markets: A Study of 14 Countries," Indian J. Financ., vol. 11, no. 9, p. 53, Sep. 2017. 
[13] B. Abdul Karim and H. Xin Ning, "Driving forces of the ASEAN-5 stock markets integration,” Asia-Pacific J. Bus. Adm., vol. 5, no. 3, pp. 186-191, Sep. 2013.

[14] L. L. K., Linkages Between ASEAN Stock Market: A Cointegration Approach. Perth: Edith Cowan University, 2007.

[15] M. A. Alvi, S. H. Chughtai, and A. Ul Haq, "Co-Movement of Pakistan Stock Market with the Stock Markets of Major Developed Countries Which Have Portfolio Investment in Pakistan,” Manag. Stud. Econ. Syst., vol. 2, no. 1, pp. 71-84, 2015.

[16] S. Suroso et al., "Autoregression Vector Prediction on Banking Stock Return using CAPM Model Approach and Multi-Factor APT," Int. J. Civ. Eng. Technol., vol. 9, no. 9, pp. 10931103, 2018.

[17] D. Xie and M. Goldstern, "The Impact of the Financial Crisis on Emerging Asia," Work. Pap., pp. 9-11, 2009.

[18] O. M. Al Nasser and M. Hajilee, "Integration of emerging stock markets with global stock markets," Res. Int. Bus. Financ., vol. 36, pp. 1-12, Jan. 2016.

[19] A. Sanusi et al., "GCG SIMULTANEITY EFFECTS, PROFIT MANAGEMENT AND VALUE OF INDONESIAN RETAIL COMPANIES,” Int. J. Civ. Eng. Technol., vol. 9, no. 7, pp. 1506-1518, 2018.

[20] Ramli, Rusiadi, Nuzuliati, A. Novalina, M. I. Indrawan, and A. P. U. Siahaan, "Innovative Technology in Increasing the Value-added of the Remnants of Fishing Trawlers in Bagan Percut Village, Percut Sei Tuan,” Int. J. Civ. Eng. Technol., vol. 9, no. 10, pp. 42-49, 2018.

[21] A. Sanusi et al., "Gravity Model Approach using Vector Autoregression in Indonesian Plywood Exports," Int. J. Civ. Eng. Technol., vol. 9, no. 10, pp. 409-421, 2018.

[22] A. Muzzamil, Analisis Pengaruh Indeks Saham Asia Tenggara terhadap Indeks Harga Saham Gabungan (JKSE) di Bursa Efek Indonesia. Jakarta, Indonesia: Universitas Pembangunan Negara "Veteran," 2011.

[23] R. Roll, "A critique of the asset pricing theory's tests Part I: On past and potential testability of the theory," J. financ. econ., vol. 4, no. 2, pp. 129-176, Mar. 1977.

[24] S. Husnan, Dasar-dasar Teori Portofolio dan Analisis Sekuritas. Yogyakarta: UPP AMPYKPN, 2005.

[25] M. Siregar et al., "Pruning Test and Enclosure Fertilizer for Growth and Production Technology of Salibu Rice," Int. J. Civ. Eng. Technol., vol. 9, no. 10, pp. 234-241, 2018.

[26] A. Setiawan et al., "Dimensions of Cultural Intelligence and Technology Skills on Employee Performance,” Int. J. Civ. Eng. Technol., vol. 9, no. 10, pp. 50-60, 2018.

[27] A. Ikhwan et al., "A Novelty of Data Mining for Promoting Education based on FP-Growth Algorithm,” Int. J. Civ. Eng. Technol., vol. 9, no. 7, pp. 1660-1669, 2018.

[28] A. Sharpe and Bailey, Investasi, Jilid Dua. Jakarta: Prenhallindo, 1999.

[29] D. R. Appleyard and A. J. Field, International Economics: Trade Theory and Policy. Irwin: McGraw-Hill, 1998.

[30] M. D. T. P. Nasution, Y. Rossanty, P. B. Sari, and A. P. U. Siahaan, "Online Shoppers Acceptance: an Exploratory Study,” Int. J. Civ. Eng. Technol., vol. 9, no. 6, pp. 793-799, 2018.

[31] Rusiadi et al., "Simultaneous Response of Dividend Policy and Value of Indonesia Manufacturing Companies An Approach of Vector Autoregression,” Int. J. Civ. Eng. Technol., vol. 9, no. 6, pp. 313-323, 2018.

[32] T. Eddy, B. Alamsyah, S. Aryza, and A. P. U. Siahaan, "An Effect Phenomena Circle Living Field in Secanggang Langkat," Int. J. Civ. Eng. Technol., vol. 9, no. 7, pp. 15751580, 2018.

[33] M. Dharma Tuah Putra Nasution, A. Putera Utama Siahaan, Y. Rossanty, and S. Aryza, "Entrepreneurship Intention Prediction using Decision Tree and Support Vector Machine,"

http://www.iaeme.com/IJCIET/index.asp 1014 editor@iaeme.com 
Rahmat Hidayat, Efrizal Adil Lubis, Rusiadi, Ade Novalina, Anwar Sanusi, A. P. U. Siahaan, Dewi Maharani Rangkuti and Lia Nazliana Nasution

in Proceedings of the Joint Workshop KO2PI and The 1st International Conference on Advance \& Scientific Innovation, 2018.

[34] Y. Rossanty, S. Aryza, M. D. T. P. Nasution, and A. P. U. Siahaan, "Design Service of QFC And SPC Methods in the Process Performance Potential Gain and Customers Value in a Company," Int. J. Civ. Eng. Technol., vol. 9, no. 6, pp. 820-829, 2018.

[35] D. Rudiger, Exchange Rates and Inflation. USA: The MIT Press, 2002.

[36] N. Trihadmini, "Contagion dan Spillover Effect Pasar Keuangan Global sebagai Early Warning System," Financ. Bank. J., vol. 13, no. 1.

[37] A. Wijayanti, "Pengaruh beberapa variabel Makro ekonomi dan Indeks Pasar Modal Dunia terhadap pergerakan Indeks Harga Saham Gabungan (IHSG) di BEI," JurnalI Imiah Univ. Brawijaya, Malang, 2013 